\title{
Synthesis and characterization of iron oxide nanoparticles reinforced polyester/nanocomposites
}

\author{
G. Naveen Kumar*1, Y. V. Mohana Reddy ${ }^{2}$, K. Hemachandra Reddy ${ }^{3}$ \\ ${ }^{1}$ Department of Mechanical Engineering, S.K.University College of Engineering \& Technology, SV \\ Puram, Kadiri Road,Anantapuramu-515655, Andhra Pradesh, India \\ ${ }^{2}$ Department of Mechanical Engineering, G Pulla Reddy Engineering College, Nandyal \\ Road, Kurnool - 518 007, Andhra Pradesh, India. \\ ${ }^{3}$ Department of Mechanical Engineering, Jawaharlal Nehru Technological University Anantapur, \\ Anantapur-515002, Andhra Pradesh, India \\ ‘E-mail address: naveeng_phd@ymail.com,yvmr2006@gmail.com, konireddy@gmail.com
}

Keywords: Nanocomposites; $\mathrm{f}-\mathrm{Fe}_{2} \mathrm{O}_{3}$ nanoparticles; Mechanical properties

\begin{abstract}
We report on synthesis of two highly disperse nanoparticles viz. $\mathrm{Fe}_{2} \mathrm{O}_{3} \&$ f-Fe $\mathrm{O}_{3}$ using chemical reduction method. Reaction was initiated to mix solution A (i.e. $\mathrm{Fecl}_{3} 6 \mathrm{H}_{2} \mathrm{O}$ ) into solution B (i.e. $\mathrm{Fecl}_{2} 4 \mathrm{H}_{2} \mathrm{O}$ ) together under the presence of ammonium to develop nanoparticles. Mechanical properties of above mentioned nanoparticles filled with polyester polymer nanocomposites were fabricated to assess the possibility of using this filler as a new material. Methacryloxypropyl was used as a functionalization agent to prepare $\mathrm{f}-\mathrm{Fe}_{2} \mathrm{O}_{3}$ nanoparticles. Mechanical properties of $\mathrm{f}-\mathrm{Fe}_{2} \mathrm{O}_{3}$ nanocomposites were improved with the help of functionalization when compared with $\mathrm{Fe}_{2} \mathrm{O}_{3}$ nanocomposites. A functionalization of nanoparticles favours the composite fabrication with a lower curing temperature as compared to the as-synthesised nanoparticles filled polyester nanocomposites. Thermogravimetric analysis showed an increased thermo-stability of f-Fe $\mathrm{O}_{3}$ nanoparticles filled polyester nanocomposites as compared to the $\mathrm{Fe}_{2} \mathrm{O}_{3}$ nanoparticles filled counterparts. Mechanical and thermal properties were increased due to the homogeneous particle dispersion and chemical bonding between nanoparticles and polyester matrix. The nanoparticles become magnetically harder after incorporation into the polyester resin matrix.
\end{abstract}

\section{INTRODUCTION}

Organic materials with both conducting and ferromagnetic properties have received tremendous attention due to their potential applications in batteries, electrochemical display devices, molecular electronics, nonlinear optics, sensors, electrical- magnetic shields and microwave-absorbants. Besides blending method by mixing physically inorganic ferromagnetic powder with conducting polymer powder, several approaches such as electrochemical and in-situ chemical polymerization have been reported to prepare conducting polymer film with ferromagnetic properties and nanocomposites with coreshell structure (Chen,et al., 2005; Podlaha and Landolt, 1997). Nanomaterials dramatically different from their bulk or atomic counterparts have attracted much interest due to their unique physicochemical properties for a wide range of potential device applications such as UV lasers, solar cells, high-sensitivity chemical gas or volatile organic compound sensors, and DNA sequence sensors (Castro, et al., 2000; Wetzel, et al.,2003; Guo, et al., 2007). Nanostructural materials such as nanoparticles (NPs) or nanofibers have been used as fillers in both the polymeric nanocomposites to improve the mechanical, electric, electronic and optical properties, and the metallic nanocomposite to control the electrodeposition. Polymer nanocomposites reinforced with inorganic nanoparticles have attracted much interest due to their lightness, homogeneity, cost-effective processability, and turntable physical properties (Kohli, et al., 2005; Judeinstein and Sanchez, 1996; Zhang, et al., 2005; Gao and Mader, 2002). Polyester resin, as a structural polymer, was chosen as a polymer matrix in current study due to the fact that the cured resins are thermosetting with a network structure possessing high resistance to the moisture and chemicals, and good mechanical properties. Thus the resultant composites have the potential 
applications in fabrication and building materials such as electrodeposition tanks, automotive parts and marine vessels which require superior mechanical properties and/or high resistance to harsh environments such as strong acid or base. Furthermore, the functional groups of the polymer surrounding the nanoparticles enable these nanocomposites as good candidates for various applications such as site-specific molecule targeting in biomedical areas (Shenhar, et al., 2005; Guo, et al., 2006; Guo, et al., 2007a; Guo, et al., 2007b). The existing challenges in the composite fabrication are to obtain uniform filler dispersion and to introduce strong chemical bonding between the nanoparticles and the polymer matrix, which are necessary to provide a high tensile strength due to local stress within the nanocomposite. The interfacial interactions between fillers and polymer matrix play a crucial role in determining the quality and properties of the nanocomposites (Rancourt and Taylor, 2008; Sawada et al., 2008; Chiang, et al., 2003). The poor bonding linkage between the fillers and the polymer matrix such as the composites made by simple mixing (Hsu, et al., 2003; Liu, et al., 1999; Park, et al., 2003; Sorensen, 2001; Zhang, et al., 1998) will introduce artificial defects, which consequently result in a adverse effect on the mechanical properties of the nanocomposites. Introducing good linkages between the fillers and the polymer matrix is still a challenge for specific composite fabrication. However, appropriate chemical engineering treatment of the nanofiller surface by introducing proper functional groups could improve both the strength and toughness of the subsequent composites with improved compatibility between the nanofillers and the polymer matrix, and make the nanocomposites stable in harsh environments as well. Thus, surface functionalization of nanoparticles with a surfactant or a coupling agent is important not only to stabilize the nanoparticle during processing but also to render them compatible with the polymer matrix. In this paper, the effect of particle functionalization by a functional methacryloxypropyl on the polyester resin curing process and the optimum conditions for high-quality nanocomposite fabrication were investigated. The $\mathrm{f}-\mathrm{Fe}_{2} \mathrm{O}_{3}$ nanocomposites reinforced polyester nanocomposites showed enhanced mechanical properties under tensile, impact and damping study. The nanocomposites containing the $\mathrm{f}-\mathrm{Fe}_{2} \mathrm{O}_{3}$ nanocomposites showed improved thermal stability as compared with the nanocomposites reinforced with the as-received $\mathrm{Fe}_{2} \mathrm{O}_{3}$ nanocomposites. The nanoparticles were found to be magnetically harder (larger coercivity) after the nanoparticles were dispersed in the polyester resin matrix.

In the present paper, $\mathrm{Fe}_{2} \mathrm{O}_{3}, \mathrm{f}-\mathrm{Fe}_{2} \mathrm{O}_{3}$ nanoparticles were synthesised by chemical reduction method. The major objective of this paper is to explore a novel approach on mechanical properties of two different nanoparticles viz. $\mathrm{Fe}_{2} \mathrm{O}_{3}, \mathrm{f}-\mathrm{Fe}_{2} \mathrm{O}_{3}$ dispersed in to the polyester nanocomposites, i.e. polyester $/ \mathrm{Fe}_{2} \mathrm{O}_{3}$, polyester/f- $\mathrm{Fe}_{2} \mathrm{O}_{3}$ nanocomposites were developed and characterized. Thus, improved mechanical properties would be expected.

\section{MATERIALS}

Unsaturated polyester (UP) with $2 \%$ cobalt accelerator, catalyst $50 \%$ methyl-ethyl-ketoneperoxide (MEKP) and 10\% DMA solution was employed in the present study supplied by Dipol 101 from Divine Petrochemicals Pvt. Ltd., India. Ratio of UP/accelerator/catalyst/promoter is 100/2/2/2 (Hsu, et al., 2003; Liu, et al., 1999). The liquid resin has a density of $1.231 \mathrm{~g} / \mathrm{cm}^{3}$ and a viscosity of 370 centipoises (cps) at room temperature. $\mathrm{Fe}_{2} \mathrm{O}_{3}$ nanoparticles with an average diameter of 10-15 $\mathrm{nm}$ and a specific surface area of $45 \mathrm{~m}^{2} / \mathrm{g}$ were functionalized and used as nanofillers for the nanocomposite fabrication. Trigonox 239-A (curing catalyst or initiator, organic peroxide, liquid) was purchased from Akzo Nobel Chemicals. Cobalt naphthenate (CoNap, OM Group, Inc.) was used as a catalyst promoter (accelerator) to decompose the catalyst at room temperature. Methacryloxypropyl-trimethoxysilane (MPS) and tetrahydrofuran (THF, anhydrous) were purchased from Sigma-Aldrich Chemical Company (Sawada et al., 2008). All the chemicals were used as-received without further treatment.

\subsection{Characterization}

Curing characteristics of polyester and polyester filled $\mathrm{Fe}_{2} \mathrm{O}_{3} \& \mathrm{f}-\mathrm{Fe}_{2} \mathrm{O}_{3}$ nanocomposites was studied using DSC. The sample (consisting of resin, $\mathrm{Fe}_{2} \mathrm{O}_{3} \&$ f- $-\mathrm{Fe}_{2} \mathrm{O}_{3}$ and hardener prior to curing) 
of $5 \mathrm{mg}$ is taken in an alumina crucible and heat is applied at the rate of $10^{\circ} \mathrm{C} \mathrm{min}$. Modal analysis is performed to calculate natural frequency and damping factor ' $n$ '. Damping factor is calculated using impulse hammer technique (IHT) and logarithmic decrement method (LDM). Specimens of $250 \mathrm{~mm} \times 25 \mathrm{~mm} \times 4 \mathrm{~mm}$ is prepared, in which one end of beam is clamped and other end is attached to accelerometer to obtain vibration modes. Natural frequency is determined by impulse loading at free end of the bean using impulse exicitation (Rion PH 7117, modally tuned hammer). The signal received from accelerometer is displayed in Fast Fourier Transform (FFT), in which natural frequency is noted down for various modes. Damping factor ' $n$ ' using IHT is determined using half power bandwidth method. The expression for damping factor by half power width technique is given by $\left(\xi=\Delta \omega / 2 \omega_{n}\right)$, where $\Delta \omega$ is bandwidth at half-power points of resonant peak for the nth mode and $\omega_{n}$ is resonant frequency. The half power points are found at $1 / \sqrt{2}$ of maximum peak value. In the LDM, sine wave signal is supplied to drive the modal exciter to excite the cantilever beam specimen (Castro, et al., 2000; Wetzel, et al., 2003). During the natural frequency mode, amplitude increases to a large extent, once the resonance is achieved. At this point, the excitation signal is disconnected freely and a typical free decay curve is obtained. From this decay curve, two experimental amplitude data points are collected namely $\mathrm{x}_{1}$ and $\mathrm{x}_{\mathrm{n}+1}$, and the damping factor $\mathrm{n}$ is calculated by using the expression

$$
\begin{aligned}
& \delta=\frac{1}{n+1} \ln \frac{x_{1}}{x_{n+1}} \\
& \xi=\frac{\delta^{2}}{\sqrt{A \pi^{2}+\delta^{2}}}
\end{aligned}
$$

Where $\xi$, the damping factor, $\mathrm{n}+1$, the number of cycles, $\delta$ is the logarithmic decrement, $\mathrm{x}_{1}$ and $\mathrm{x}$ ${ }_{n+1}$ are the two displacement values at the time intervals $t_{1}$ and $t_{2}$, respectively. A Jeol JSM 840A Japan scanning electron microscope (SEM) was used to study the morphology of fractured surfaces of after tensile test of $\mathrm{Fe}_{2} \mathrm{O}_{3} \& \mathrm{f}-\mathrm{Fe}_{2} \mathrm{O}_{3}$ nanocomposites with different magnifications. Samples were gold-coated initially subjected to SEM analysis. The scanning electron micrograms of different cross-sections of the nanocomposites of pure polyester filled with $\mathrm{Fe}_{2} \mathrm{O}_{3} \& \mathrm{f}-\mathrm{Fe}_{2} \mathrm{O}_{3}$ nanocomposites were studied. Tensile strength was studied by using universal testing machine (UTM) supplied by Instron Corporation; 3369, series-9 was used with a crosshead speed of $5 \mathrm{~mm} / \mathrm{min}$. Testing samples were prepared like dumb-bell shapes and its dimensions are $\left(100 \times 20 \times 3 \mathrm{~mm}^{3}\right)$ prepared based on the ASTM D 638 standards. In each case, five samples were tested and the average value tabulated. The thermal characteristics of the $\mathrm{Fe}_{2} \mathrm{O}_{3} \& \mathrm{f}-\mathrm{Fe}_{2} \mathrm{O}_{3}$ filled with polyester nanocomposites were measured using both differential scanning calorimetry (DSC-2010 TA Instrument) and thermogravimetric analyses (TGA) at a rate of $10^{\circ} \mathrm{C} / \mathrm{min}$ under nitrogen flow.

\subsection{Preparation of ferrite-nanoparticles}

Reaction was carried out by mixing two solutions, named as solution A (i.e. $\mathrm{Fecl}_{3} 6 \mathrm{H}_{2} \mathrm{O}$ ) and solution B (i.e. $\mathrm{Fecl}_{2} 4 \mathrm{H}_{2} \mathrm{O}$ ) to form nanoparticles. 0.1 Mole of $27.030 \mathrm{gms}$ of solution A was dissolved $1000 \mathrm{ml}$ deionised water, whereas, 19.881gms of solution B was dissolved in $1000 \mathrm{ml}$ deionised water used were to prepare solutions. Then solution A was added then to solution B drop wise by 2:1 stoichiometric ratio under vigorous stirring. Ammonium $(45 \mathrm{ml})$ was dropped in to the mixture; forthwith black powder was produced in less than one second. After reaction, the product particles were separated from the solution by a strong magnet and washed with deionised water. Freeze-drying overnight was utilized to dry the particles.

\subsection{Surface functionalization of iron oxide nanoparticles}

The nanoparticles functionalization follow procedures similar to our earlier reported nanoparticle process (Guo,et al.,2007a; Guo,et al.,2007b) and is described as follows. $\mathrm{Fe}_{2} \mathrm{O}_{3}$ nanoparticles $(13.38 \mathrm{~g}, 83.8 \mathrm{~mol})$ were added into a mixture of $4 \mathrm{~g}$ Methacryloxypropyl and $30 \mathrm{ml}$ THF. The resulting colloidal suspension was ultrasonically stirred (Branson 1510) for $1 \mathrm{~h}$ and 
precipitated by a permanent magnet at room temperature. The precipitated nanoparticles were rinsed with THF to remove excessive Methacryloxypropyl for subsequent nanocomposite fabrication and the dried nanoparticles were used for further particle characterization. The asreceived $\mathrm{Fe}_{2} \mathrm{O}_{3}$ nanoparticles or MPS functionalized $\mathrm{Fe}_{2} \mathrm{O}_{3}$ nanoparticles were dispersed into $30 \mathrm{ml}$ resin on a specific weight percentage basis. The dispersion was carried out in an ice-water ultrasonic bath for about $1 \mathrm{~h}$. The above particle-suspended solution was then ultrasonically stirred in an ice-water ultrasonic bath until the temperature was cooled down. Then, $2.0 \mathrm{wt} \%$ catalyst (initiator) was added into the iron-nanoparticles which was stirred and degassed for $2 \mathrm{~min}$. Next, 0.3 $\mathrm{wt} \%$ promoter was added and mixed quickly. The mixed viscous solution was poured into silicone rubber molds. The curing via free-radical bulk copolymerization or homopolymerization initiated by the catalyst was done at $85{ }^{\circ} \mathrm{C}$ for $1 \mathrm{~h}$ under normal atmospheric conditions and cooled down to room temperature naturally in the oven following procedures similar to those used for our reported alumina nanoparticles filled polyester resin nanocomposites fabrication (Judeinstein and Sanchez, 1996). A viscous liquid solution was still observed in the mold after this curing process, indicating that nanofilling materials have a significant effect on the quality of fabricated nanocomposites. However, high-quality nanocomposites were formed by room temperature curing for $24 \mathrm{~h}$ followed by post curing at $100^{\circ} \mathrm{C}$ for 2 hours.

\section{RESULTS AND DISCUSSIONS}

The tensile fracture surfaces of polyester and polyester filled $\mathrm{f}-\mathrm{Fe}_{2} \mathrm{O}_{3}$ are shown in Figure 1.It is learnt from the cross section of fractured surface of pure polyester is smooth due to brittle failure. However, on addition of $\mathrm{f}-\mathrm{Fe}_{2} \mathrm{O}_{3}$ particles, crack surface becomes rough. The roughness increases as $\mathrm{f}-\mathrm{Fe}_{2} \mathrm{O}_{3}$ content increases in the matrix. The fracture roughness indicates that the resistance of propagation of crack is small and the crack has not propagated as easily as seen in pure polyester. The fracture surface roughness indicates that crack propagation is large and increased the torturous path of propagating crack (Kohli, et al., 2005; Judeinstein and Sanchez, 1996). This effect results in higher stress to failure and caused improved strength of $\mathrm{f}-\mathrm{Fe}_{2} \mathrm{O}_{3}$ nanocomposites. Though the fracture roughness is predominant at $6 \% \mathrm{f}-\mathrm{Fe}_{2} \mathrm{O}_{3}$, the existence of unexfolaited aggregates, voids, etc. could have decreased the strength of $\mathrm{f}-\mathrm{Fe}_{2} \mathrm{O}_{3}$. The fracture surface of polyester with $\mathrm{Fe}_{2} \mathrm{O}_{3}$ series is seen in Figure 2. Fracture surface of polyester with $1 \% \mathrm{Fe}_{2} \mathrm{O}_{3}$ is rougher than pure polyester. At $6 \% \mathrm{f}-\mathrm{Fe}_{2} \mathrm{O}_{3}$, the presence of voids is noted. This indicates that particles have peeled off from material as crack propagates, and create void at the positions where $\mathrm{Fe}_{2} \mathrm{O}_{3}$ particles were present. This also indicates that bonding between matrix and $\mathrm{Fe}_{2} \mathrm{O}_{3}$ particle is poor. From both Figures, it is learnt that at $3 \mathrm{wt} . \% \mathrm{f}-\mathrm{Fe}_{2} \mathrm{O}_{3}$ the roughness was more predominant in the Fig. 1 than the Fig.2. In the Fig. 2 at 6 wt. $\% \mathrm{Fe}_{2} \mathrm{O}_{3}$, though the fracture surface is rough though, due to the existence of voids is clearly visible and has decreased the strength of the material. The poor bonding strength, smooth fracture surface, voids, etc. could decrease the tensile strength of the $\mathrm{Fe}_{2} \mathrm{O}_{3}$ filled polyester nanocomposites. In polyester $/ \mathrm{Fe}_{2} \mathrm{O}_{3}$ series, though the tensile strength increases up to $3 \% \mathrm{Fe}_{2} \mathrm{O}_{3}$, for higher nanoparticles content, it decreases due to unexfoliated aggregates, voids, etc. However, the strength of $\mathrm{f}-\mathrm{Fe}_{2} \mathrm{O}_{3}$ nanocomposites are significantly improved than the $\mathrm{Fe}_{2} \mathrm{O}_{3}$ nanocomposites. It requires further investigation of the synthetic procedure to understand the methods of improving tensile strength for higher nanocontents. Figure 3 shows SEM picture of polyester with $6 \% \mathrm{f}-\mathrm{Fe}_{2} \mathrm{O}_{3}$ consisting of voids.

DSC scans of polyester filled with $\mathrm{f}-\mathrm{Fe}_{2} \mathrm{O}_{3}$, polyester filled with $\mathrm{Fe}_{2} \mathrm{O}_{3}$ nanocomposites are shown in Figure 4. At $1 \mathrm{wt} \% \mathrm{f}-\mathrm{Fe}_{2} \mathrm{O}_{3}$ addition, the peak position was decreased to lower temperature as shown in Figure $4 \mathrm{a}$. At higher $\mathrm{wt} \% \mathrm{f}-\mathrm{Fe}_{2} \mathrm{O}_{3}$ nanodispersion two distinct peaks were noticed, one at lower temperature and another at higher temperature. The higher temperature peak is noticed at curing peak of $1 \mathrm{wt} \% \mathrm{f}-\mathrm{Fe}_{2} \mathrm{O}_{3}$ nanocomposites. The lower temperature peak corresponds to curing of polyester resin in intergallery region, and higher temperature peak corresponds to curing at extragallery (matrix) region. As $\mathrm{f}-\mathrm{Fe}_{2} \mathrm{O}_{3}$ content increases above $3 \mathrm{wt} \%$ the lower temperature peak decreases and for $6 \mathrm{wt} \% \mathrm{f}-\mathrm{Fe}_{2} \mathrm{O}_{3}$ it is at $420^{\circ} \mathrm{C}$. Single exothermic peaks was noted for polyester with $\mathrm{f}-\mathrm{Fe}_{2} \mathrm{O}_{3}$ content up to $3 \mathrm{wt} \% \mathrm{f}-\mathrm{Fe}_{2} \mathrm{O}_{3}$ and results in uniform polymerization. 
This uniform polymerization at intergallery region and extragallery (matrix) region could have favoured the exfoliated structure. At higher $\mathrm{Fe}_{2} \mathrm{O}_{3}$ content (i.e. $3 \mathrm{wt} \%$ ), the uneven polymerization occurs in the nanocomposites and this leads to two distinct curing exothermic peaks. The intergallery polymerization occurs at lower temperature and cures quicker than that of the extragallery polymerization. Due to this quick intergallery polymerization, the iron nanolayers cannot separate further. This uneven polymerization leads to the formation of intercalated structures for higher $\mathrm{f}-\mathrm{Fe}_{2} \mathrm{O}_{3}$ content (above $3 \mathrm{wt} \%$ ). The DSC curing scans of polyester filled with $\mathrm{Fe}_{2} \mathrm{O}_{3}$ are shown in Fig. 4b. It is seen that the addition of $\mathrm{Fe}_{2} \mathrm{O}_{3}$ does not shift the exothermic peak, which is noted for $\mathrm{f}-\mathrm{Fe}_{2} \mathrm{O}_{3}$ contents in the Fig.4a. The result suggests that addition of $\mathrm{Fe}_{2} \mathrm{O}_{3}$ in polyester resin does not affect the curing of polyester. The addition of $\mathrm{f}-\mathrm{Fe}_{2} \mathrm{O}_{3}$ and $\mathrm{Fe}_{2} \mathrm{O}_{3}$ fillers in the polyester decreases the intensity of exothermic peak. The addition of $\mathrm{Fe}_{2} \mathrm{O}_{3}$ continuously decreases the exothermic peak and this is due to decrease in concentration of polyester resin on the addition of nanoparticles. It is stated that the presence of organ ions in $\mathrm{f}-\mathrm{Fe}_{2} \mathrm{O}_{3}$ increases the polymerization of polyester by catalytic effect attributed the increase of curing temperature (Rancourt and Taylor, 2008). However, the existence of $\mathrm{f}^{-} \mathrm{Fe}_{2} \mathrm{O}_{3}$ affects the polymerization of polyester. Results shows that the effect of $\mathrm{f}-\mathrm{Fe}_{2} \mathrm{O}_{3}$ restricting the polymerization is more than the polymerization of $\mathrm{Fe}_{2} \mathrm{O}_{3}$ with polyester polymer, and hence decreases the curing temperature of polyester resin.

Figure 5 shows TGA curves of polyester filled with two different nanoparticles such as $\mathrm{Fe}_{2} \mathrm{O}_{3}$ and $\mathrm{f}-\mathrm{Fe}_{2} \mathrm{O}_{3}$ nanocomposites. Figure 5 (a) shows thermal stability ,of $1 \mathrm{wt} . \%$ and $3 \mathrm{wt} . \% \mathrm{Fe}_{2} \mathrm{O}_{3}$ nanocomposites does not show much difference between the both wt.\% ratios as both the curves merged up to $300^{\circ} \mathrm{C}$ and it is due to dissociation of iron oxide ions. It is also learnt that due to the moisture content in the $\mathrm{Fe}_{2} \mathrm{O}_{3}$ nanoparticles the decomposition was started at $100^{\circ} \mathrm{C}$. On addition of $6 \mathrm{wt} \% \mathrm{Fe}_{2} \mathrm{O}_{3}$ in polyester, the thermal stability was increased up to $325^{\circ} \mathrm{C}$. The hard iron-oxide layers act as barrier for volatile degradation of polyester matrix. This effect causes such enhanced thermal properties of nanocomposites. The enhanced thermal stability of $\mathrm{Fe}_{2} \mathrm{O}_{3}$ nanocomposites was observed even at higher temperature $\left(>400{ }^{\circ} \mathrm{C}\right)$ was due to the existence of inorganic phases $\left(\mathrm{SiO}_{2}\right.$, $\mathrm{Al}_{2} \mathrm{O}_{3}, \mathrm{MgO}$, etc) (Park, et al., 2003; Sorensen, 2001) dominates the iron-nanocomposites. Figure $5 \mathrm{~b}$ shows decomposition of polyester filled with $\mathrm{f}-\mathrm{Fe}_{2} \mathrm{O}_{3}$ nanoparticles. From the Fig.5b shows weight loss was remain constant up to $150^{\circ} \mathrm{C}$. This is the clear indication, through functionalization of iron-oxide nanoparticles moisture content is reduced some extent. And also thermal stability was increased to $305^{\circ} \mathrm{C}$ for $1 \mathrm{wt} . \% \mathrm{f}-\mathrm{Fe}_{2} \mathrm{O}_{3}$ whereas for 3 and $6 \mathrm{wt} . \% \mathrm{f}-\mathrm{Fe}_{2} \mathrm{O}_{3}$ up to $330^{\circ} \mathrm{C}$ and $335^{\circ} \mathrm{C}$ respectively. Another significant point come to light is decomposition temperature for $\mathrm{f}-\mathrm{Fe}_{2} \mathrm{O}_{3}$ nanoparticles were changed dramatically than $\mathrm{Fe}_{2} \mathrm{O}_{3}$ nanoparticles. There is a marginal shift in decomposition temperature when $\mathrm{f}-\mathrm{Fe}_{2} \mathrm{O}_{3}$ is added in to the polyester. The improved thermal stability is noticed for polyester filled $\mathrm{f}-\mathrm{Fe}_{2} \mathrm{O}_{3}$ series is higher temperatures (i.e. $335^{\circ} \mathrm{C}$ ) than pure iron-oxide nanoparticles.

Figure 6 (a) and (b) shows the effect of addition of $\mathrm{Fe}_{2} \mathrm{O}_{3}$ and $\mathrm{f}-\mathrm{Fe}_{2} \mathrm{O}_{3}$ nanoparticles filled polyester nanocomposites on tensile strength and tensile modulus. The tensile strength of pure polyester is $41.1 \mathrm{MPa}$ which can be seen in the Fig. 6 (a). It is increased up to $3 \mathrm{wt} \%$ for both composites, decreases when further dispersion. On other hand, tensile strength was increased up to $3 \mathrm{wt} . \%$, decreases in further addition of $\mathrm{f}-\mathrm{Fe}_{2} \mathrm{O}_{3}$ filled polyester nanocomposites. Tensile strength was optimized at $3 \mathrm{wt} . \%$ for $\mathrm{Fe}_{2} \mathrm{O}_{3}$ and $\mathrm{f}-\mathrm{Fe}_{2} \mathrm{O}_{3}$. When nanoparticles are functionalized, it left off exfoliated structures at 3\% is the clear indication of higher performance for the $\mathrm{f}-\mathrm{Fe}_{2} \mathrm{O}_{3}$ when compared with $\mathrm{Fe}_{2} \mathrm{O}_{3}$. The formation of intercalated structure, agglomeration, presence of voids, etc., above 3\% iron-oxide has decreased the strength of the nanocomposites. In the Fig. 6(b), tensile modulus is increased up to $3.5 \mathrm{wt} . \%$, decreases further increase. On the other hand, the tensile modulus of $\mathrm{Fe}_{2} \mathrm{O}_{3}$ and $\mathrm{f}-\mathrm{Fe}_{2} \mathrm{O}_{3}$ nanocomposites increased with particle content, no matter the specimens were functionalized or not, as shown in Fig. 6(b). This is because the surface modified or not modified nanoparticles reinforced the composites successfully (Zhang, et al., 1998). The $\mathrm{Fe}_{2} \mathrm{O}_{3}$ particles did not make the remarkable difference in tensile modulus at a lower given particle content. This is because the tensile modulus is measured at small deformation. At this stage, the $\mathrm{Fe}_{2} \mathrm{O}_{3}$ molecules do not respond to the deformation. But at higher filler content, due to the increase in 
viscosity of the particle causes agglomerations, and void induces poor stress transfer, therefore, beyond 3.5wt.\% tensile modulus was decreased. The orientation of iron platelets and polymer chains with respect to loading direction can also contribute to reinforcement effects. The decreasing rate of modulus at higher $\mathrm{Fe}_{2} \mathrm{O}_{3}$ content $\left(>3.5 \% \mathrm{Fe}_{2} \mathrm{O}_{3}\right)$ is due to presence of not exfoliated aggregates in polyester matrix. In polyester/ $\mathrm{f}-\mathrm{Fe}_{2} \mathrm{O}_{3}$ composites, there was not much improvement in modulus due to the absence of homogeneous $\mathrm{Fe}_{2} \mathrm{O}_{3}$ distribution at molecular level, and hence does not contribute to molecular strength. The tensile fracture surfaces of polyester filled $\mathrm{f}-\mathrm{Fe}_{2} \mathrm{O}_{3}$ and $\mathrm{Fe}_{2} \mathrm{O}_{3}$ are shown in Fig. 1. Fig. 2 shows the fracture surface of polyester filled $\mathrm{Fe}_{2} \mathrm{O}_{3}$ and f$\mathrm{Fe}_{2} \mathrm{O}_{3}$ particles. If it seen from Fig. 1 that fracture surface of pure polyester is smooth due to brittle failure. However, on addition of $\mathrm{Fe}_{2} \mathrm{O}_{3}$ particles, crack surface becomes rough (i.e. ductile nature). The roughness increases as $\mathrm{Fe}_{2} \mathrm{O}_{3}$ content increases in the matrix. The fracture roughness indicates that the resistance of propagation of crack is large and the crack has not propagated as easily as seen in pure polyester. The fracture surface roughness indicates that crack propagation is large and increased the torturous path of propagating crack (Chiang, et al., 2003). This effect results in higher stress to failure and caused improved strength of $\mathrm{Fe}_{2} \mathrm{O}_{3}$-nanocomposites.

\subsection{Impact properties}

Impact results of polyester filled with $\mathrm{Fe}_{2} \mathrm{O}_{3}$ and $\mathrm{f}-\mathrm{Fe}_{2} \mathrm{O}_{3}$ nanocomposites are shown in Fig. 7. It is seen that impact strength is increased up to $2.5 \mathrm{wt} . \% \mathrm{Fe}_{2} \mathrm{O}_{3}$ and further addition of $\mathrm{Fe}_{2} \mathrm{O}_{3}$ decreases the impact strength. The decrease in impact strength at higher filler content is due to the existence of agglomeration, not exfoliated aggregates, voids, etc. The addition of $f-\mathrm{Fe}_{2} \mathrm{O}_{3}$ in polyester decreases the impact strength of polyester/nanocomposites beyond 3\%. The impact strength results shows that $\mathrm{f}-\mathrm{Fe}_{2} \mathrm{O}_{3}$ nanocomposites provide better impact properties than $\mathrm{Fe}_{2} \mathrm{O}_{3}$ filled polyester composites. Figure 1, 2, and 3 shows the impact fracture surface of nanocomposites. The impact fracture surface provides the reason for impact properties in nanocomposites. Figure 1 shows that fracture surface of pure polyester is smooth and was indicating brittle failure. The addition of $1 \% \mathrm{Fe}_{2} \mathrm{O}_{3}$, fracture surface shows rough morphology. The roughness of the fracture surface increases as $\mathrm{Fe}_{2} \mathrm{O}_{3}$ content increases to $2.5 \% \mathrm{Fe}_{2} \mathrm{O}_{3}$. The existence of rough surface shows that crack propagation is difficult and could have increased the torturous path and leads to high strength to failure. This has caused high impact strength of $\mathrm{Fe}_{2} \mathrm{O}_{3}$ nanocomposites up to the addition of $2.5 \mathrm{wt} \% \mathrm{Fe}_{2} \mathrm{O}_{3}$, and on higher addition. Impact results suggest that some additional energy absorbing mechanism is taking place when $\mathrm{f}-\mathrm{Fe}_{2} \mathrm{O}_{3}$ particles are reinforced in matrix. Crack pinning, cavitations mechanisms, crack surface roughness, etc. (Gao and Mader, 2002) are the possible reasons for high impact strength for $\mathrm{f}-\mathrm{Fe}_{2} \mathrm{O}_{3}$ filled polyester higher than that of $\mathrm{Fe}_{2} \mathrm{O}_{3}$ filled polyester, hence Table 1 shows the effect of $\mathrm{Fe}_{2} \mathrm{O}_{3}$ addition on natural frequency of polyester. Pure polyester shows natural frequency of $17.56,118.53,120.53$ and $298.34 \mathrm{~Hz}$ for 1 st four modes of vibrations, respectively. On addition of $\mathrm{Fe}_{2} \mathrm{O}_{3}$, natural frequencies of all modes are higher than the polyester. For higher $\mathrm{Fe}_{2} \mathrm{O}_{3}$ content ( $>3 \mathrm{wt} \%$ ), natural frequency decreases, however higher than that of pure polyester. The large increase in stiffness due to the reinforcement of $\mathrm{Fe}_{2} \mathrm{O}_{3}$ in the matrix causes such increased natural frequency. For higher $\mathrm{Fe}_{2} \mathrm{O}_{3}$ content, the presence of not exfoliated aggregates of $\mathrm{Fe}_{2} \mathrm{O}_{3}$ reduces the stiffness, which decreases the natural frequency. Table 2 shows the effect of $\mathrm{f}-\mathrm{Fe}_{2} \mathrm{O}_{3}$ addition on natural frequency of polyester. The $\mathrm{Fe}_{2} \mathrm{O}_{3}$ addition does not improve the natural frequency of polyester as is seen in the case of $\mathrm{f}-\mathrm{Fe}_{2} \mathrm{O}_{3}$ filler additions. A negligible effect in stiffness on reinforcement of $\mathrm{Fe}_{2} \mathrm{O}_{3}$ in polyester polymer matrix causes such low natural frequencies. Figure 8 (a) and (b) shows the effect of $\mathrm{Fe}_{2} \mathrm{O}_{3}$ and $\mathrm{f}-\mathrm{Fe}_{2} \mathrm{O}_{3}$ addition on damping characteristics of polyester nanocomposites. Damping factors measured by LDM and IHT methods for $1 \mathrm{st}$ and 4th mode of natural frequencies are presented. Damping factors measured for 1st mode of natural frequencies of epoxy with $\mathrm{Fe}_{2} \mathrm{O}_{3}$ and $\mathrm{f}-\mathrm{Fe}_{2} \mathrm{O}_{3}$ series are shown in Fig. 8a. It is observed that both the $\mathrm{Fe}_{2} \mathrm{O}_{3}$ and $\mathrm{f}-\mathrm{Fe}_{2} \mathrm{O}_{3}$ addition increases the damping factors of pure polyester. $\mathrm{The}_{2} \mathrm{Fe}_{2} \mathrm{O}_{3}$ filled polyester increases the damping factor than that of $\mathrm{f}-\mathrm{Fe}_{2} \mathrm{O}_{3}$ filled polyester polymer. Damping factor measured by IHT shows higher values than that of measured by LDM. The free load during impact causes increased damping in IHT. Since no free load is acting in LDM, and hence damping 
factor is less than that of IHT. It is seen that damping factor increases up to $3 \mathrm{wt} \%$ of $\mathrm{Fe}_{2} \mathrm{O}_{3}$, and for higher $\mathrm{Fe}_{2} \mathrm{O}_{3}$ addition in polyester, damping factor decreases but above the value of matrix material. The increased stiffness due to the addition of $\mathrm{Fe}_{2} \mathrm{O}_{3}$ improves damping factor (Liu, et al., 1999). Similar effect in damping is noted for 4th mode of natural frequency of epoxy filled $\mathrm{Fe}_{2} \mathrm{O}_{3}$ and $\mathrm{f}$ $\mathrm{Fe}_{2} \mathrm{O}_{3}$ series as shown in Fig. 8(b). Though the addition of $\mathrm{f}-\mathrm{Fe}_{2} \mathrm{O}_{3}$ shows improvement in damping factor, the values are lesser than that of $\mathrm{Fe}_{2} \mathrm{O}_{3}$ filled polyester polymer.
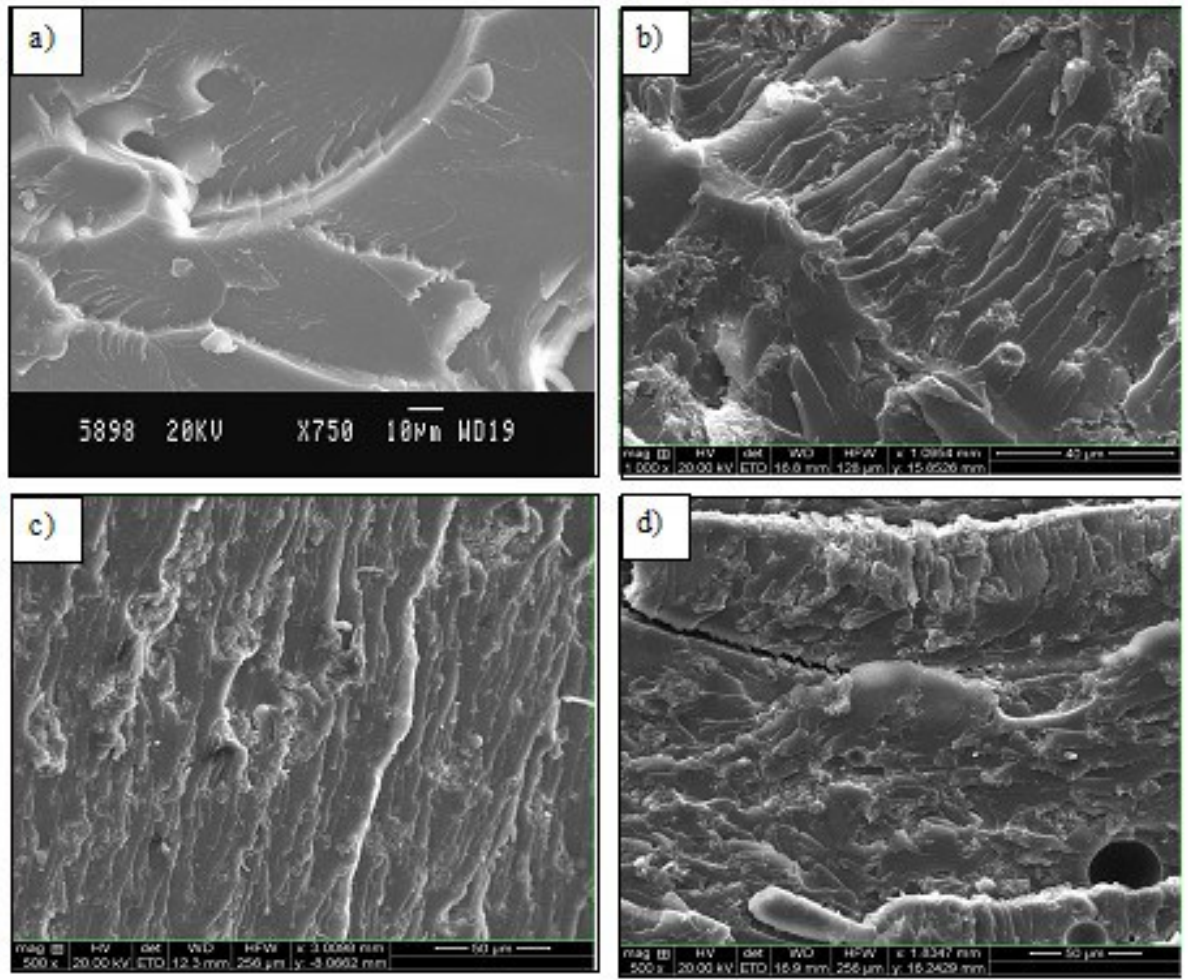

Figure $1 \mathrm{SEM}$ analysis on tensile fracture surface of (a) pure polyester (P) (b) $\mathrm{P}+1 \% \mathrm{f}-\mathrm{Fe}_{2} \mathrm{O}_{3}$, (c) $\mathrm{P}+3 \% \mathrm{f}-\mathrm{Fe}_{2} \mathrm{O}_{3}$ and (d) $\mathrm{P}+6 \% \mathrm{f}-\mathrm{Fe}_{2} \mathrm{O}_{3}$ nanocomposites.
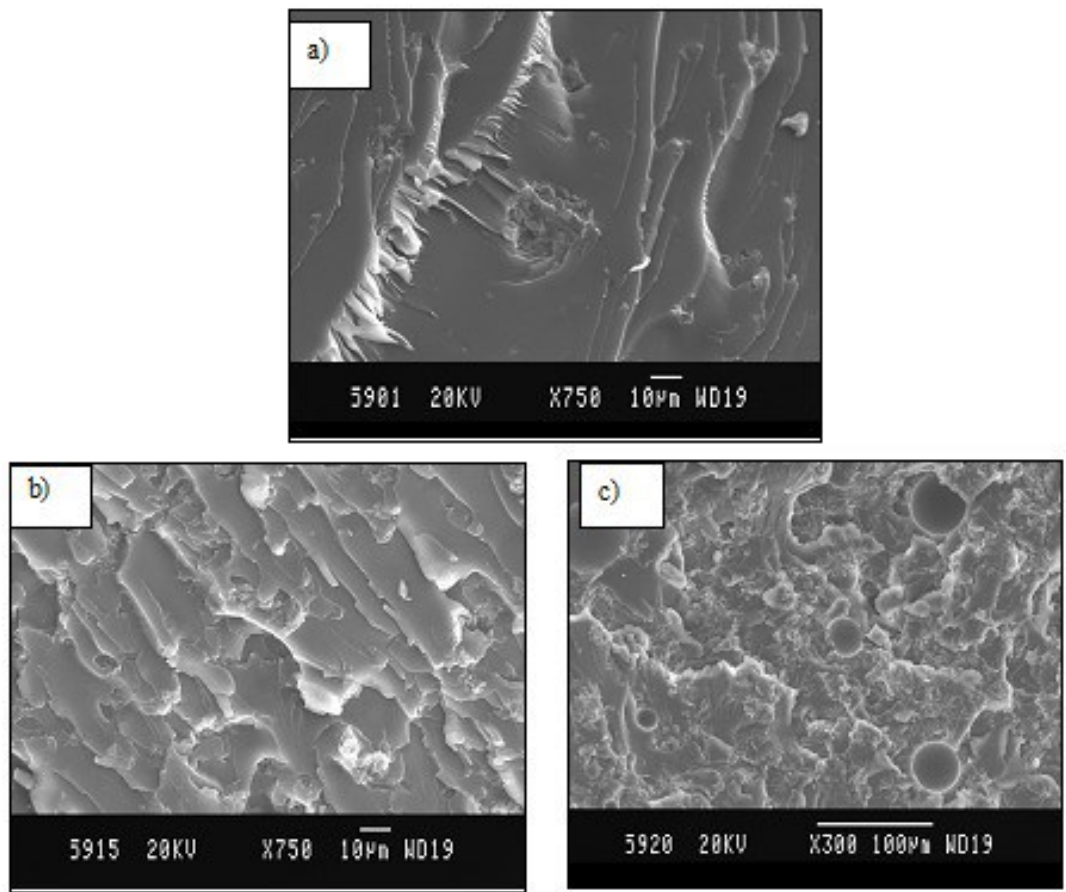

Figure 2 SEM analysis on tensile fracture surface of (a) Polyester (P) $+1 \% \mathrm{Fe}_{2} \mathrm{O}_{3}$, (b) $\mathrm{P}+3 \%$ $\mathrm{Fe}_{2} \mathrm{O}_{3}$ and (c) $\mathrm{P}+6 \% \mathrm{Fe}_{2} \mathrm{O}_{3}$. 


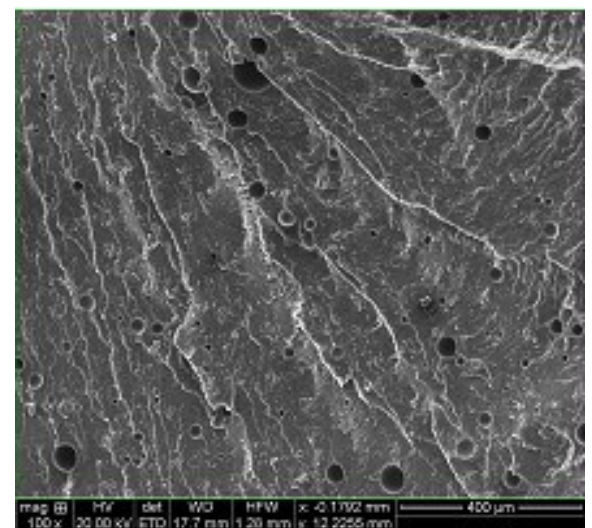

Figure 3 SEM analysis on tensile fracture surface of $\mathrm{P}+6 \% \mathrm{f}-\mathrm{Fe}_{2} \mathrm{O}_{3}$ nanocomposites.
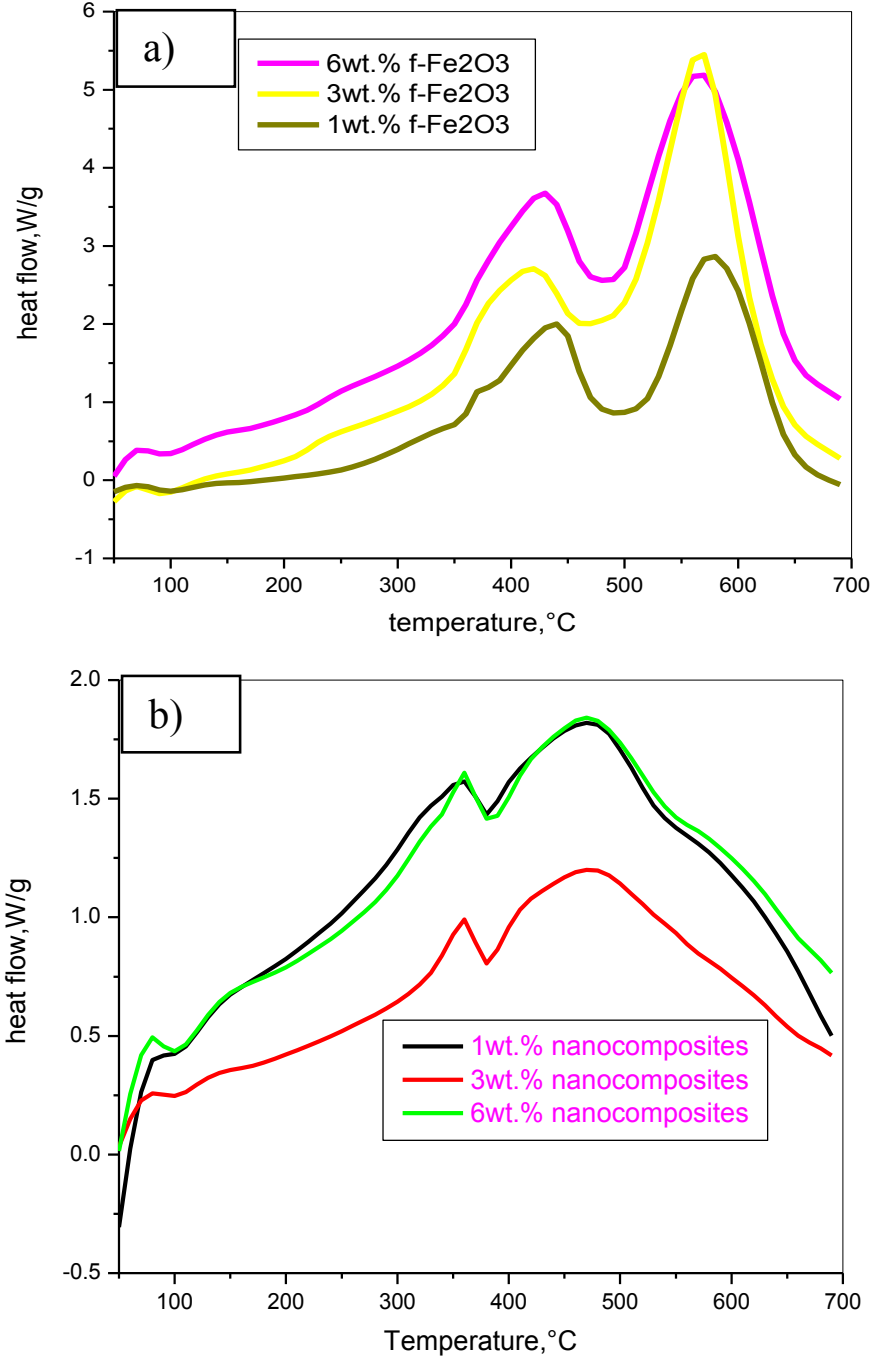

Figure 4. DSC scans of (a) polyester with $\mathrm{f}-\mathrm{Fe}_{2} \mathrm{O}_{3}$ series (b) Polyester with $\mathrm{Fe}_{2} \mathrm{O}_{3}$ series. 

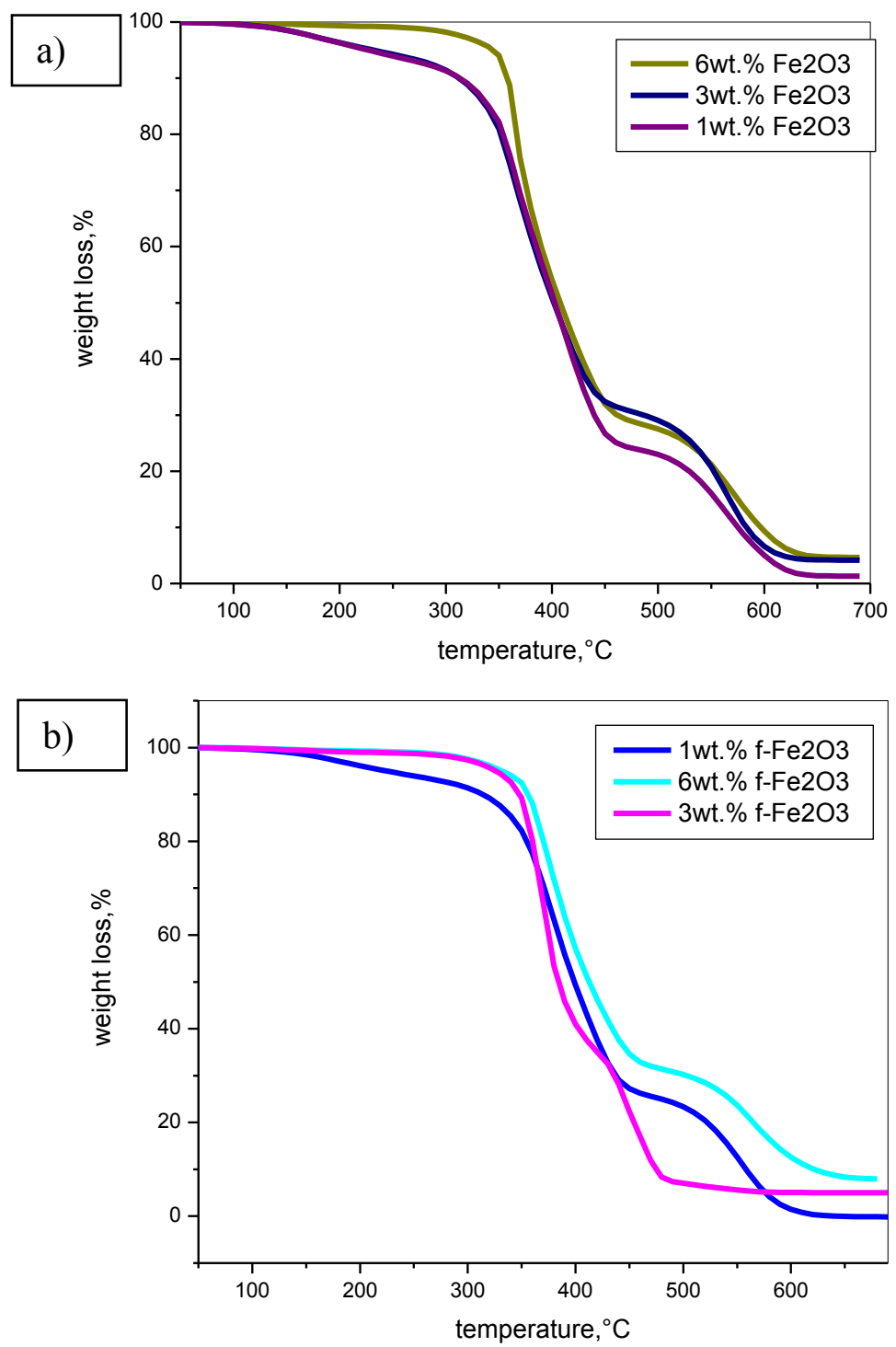

Figure 5. TGA thermographs of polyester with (a) $\mathrm{Fe}_{2} \mathrm{O}_{3}$ and (b) $\mathrm{f}-\mathrm{Fe}_{2} \mathrm{O}_{3}$ composite series.

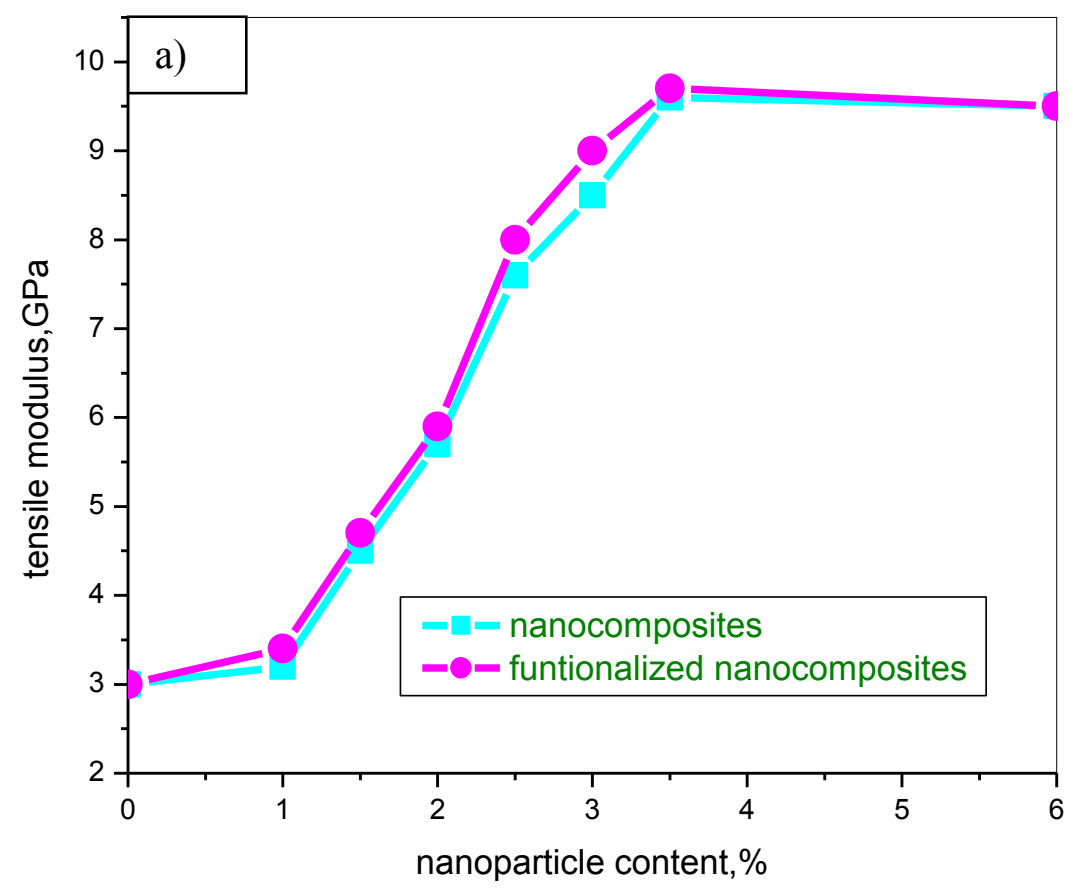




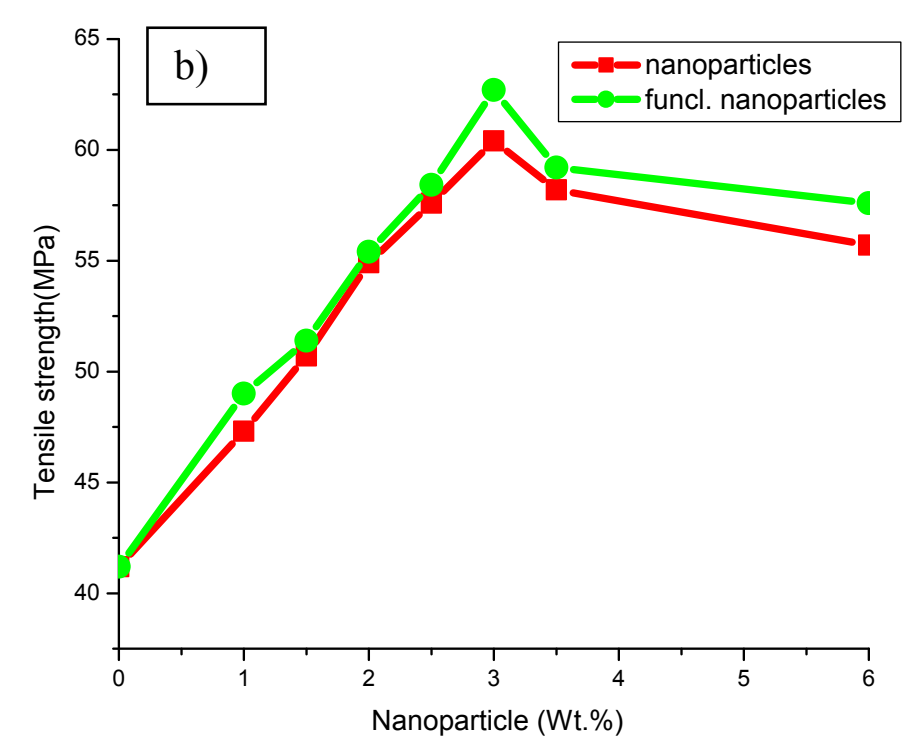

Figure 6 Effect of $\mathrm{Fe}_{2} \mathrm{O}_{3} / \mathrm{f}-\mathrm{Fe}_{2} \mathrm{O}_{3}$ content on (a) tensile strength and (b) tensile modulus

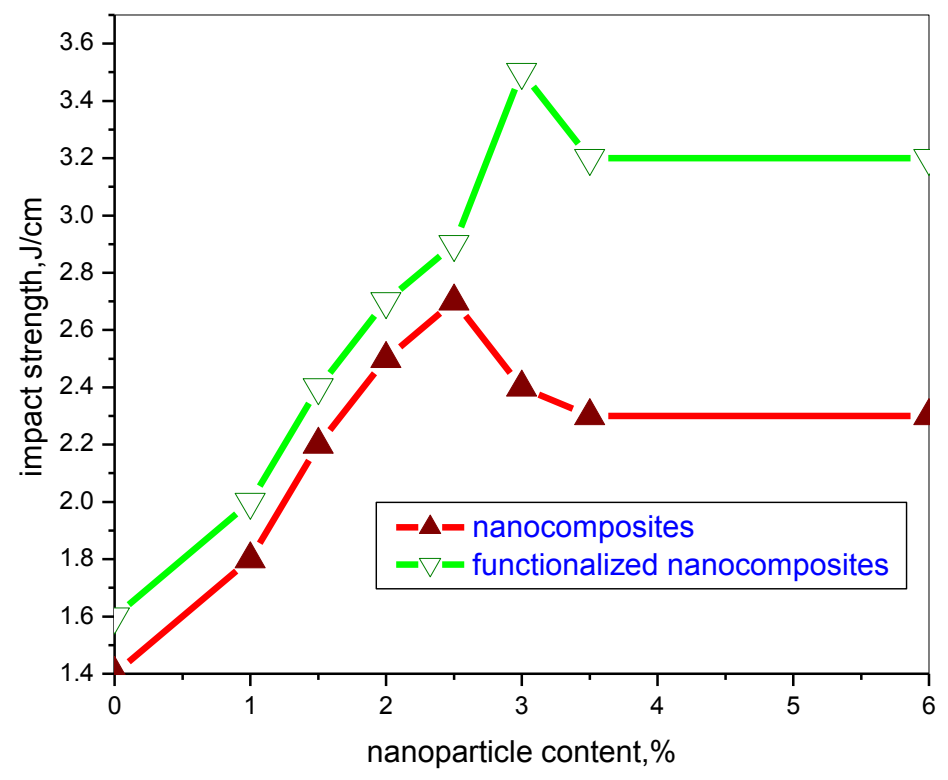

Figure 7Effect of impact strength of polyester filled with $\mathrm{Fe}_{2} \mathrm{O}_{3}$ and $\mathrm{f}-\mathrm{Fe}_{2} \mathrm{O}_{3}$ nanocomposite series. 

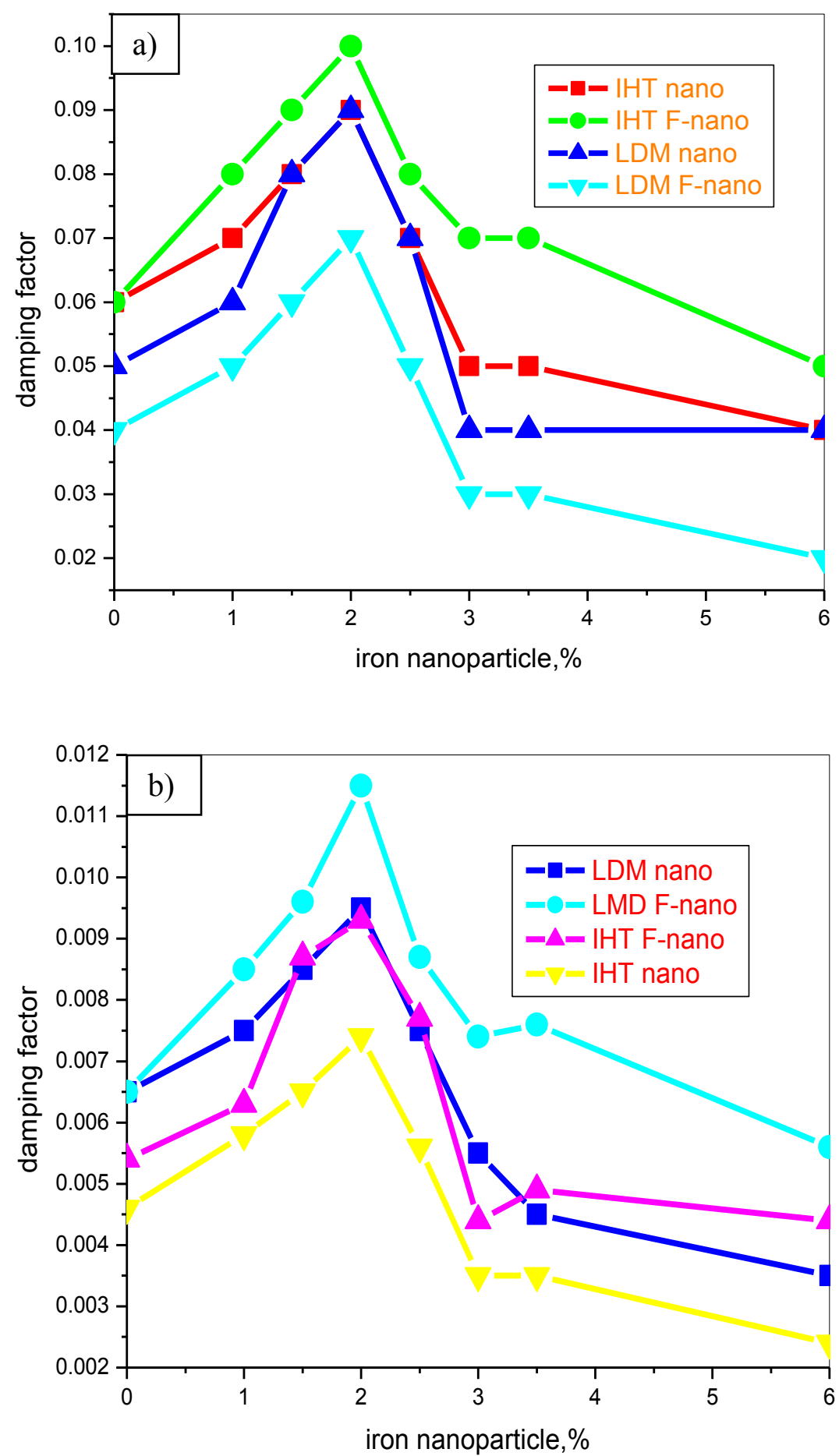

Figure 8 Damping factor for polyester with $\mathrm{Fe}_{2} \mathrm{O}_{3}$ and $\mathrm{f}-\mathrm{Fe}_{2} \mathrm{O}_{3}$ series at (a) $1^{\text {st }}$ mode and (b) 2 nd mode. 
Table 1 Frequency dependence of polyester filled with nanoparticles $\left(\mathrm{f}-\mathrm{Fe}_{2} \mathrm{O}_{3}\right)$ at four different modes.

\begin{tabular}{ccccc}
\hline $\begin{array}{c}\text { Polyester }+ \\
\left.\text { wt.\% f-Fe } \mathrm{O}_{3}\right)\end{array}$ & $\begin{array}{c}\text { Natural } \\
\text { Frequency at } \\
\text { mode 1, Hz }\end{array}$ & $\begin{array}{c}\text { Natural } \\
\text { Frequency at } \\
\text { mode 2, Hz }\end{array}$ & $\begin{array}{c}\text { Natural } \\
\text { Frequency at } \\
\text { mode 3, Hz }\end{array}$ & $\begin{array}{c}\text { Natural } \\
\text { Frequency at } \\
\text { mode 4, Hz }\end{array}$ \\
\hline $\mathrm{P}+0.0$ & 14.66 & 100.10 & 140.00 & 195.00 \\
$\mathrm{P}+1.0$ & 17.23 & 122.07 & 153.75 & 200.05 \\
$\mathrm{P}+1.5$ & 19.51 & 124.96 & 161.75 & 230.42 \\
$\mathrm{P}+2.0$ & 20.40 & 135.08 & 184.63 & 248.43 \\
$\mathrm{P}+2.5$ & 21.20 & 137.04 & 214.06 & 258.26 \\
$\mathrm{P}+3.0$ & 23.24 & 139.50 & 220.75 & 278.43 \\
$\mathrm{P}+3.5$ & 18.23 & 130.45 & 201.43 & 261.23 \\
$\mathrm{P}+6.0$ & 18.01 & 131.09 & 200.55 & 260.34 \\
\hline
\end{tabular}

Note: P-Polyester

Table 2 Frequency dependence of polyester filled with nanoparticles $\left(\mathrm{Fe}_{2} \mathrm{O}_{3}\right)$ at four different modes.

\begin{tabular}{ccccc}
\hline $\begin{array}{c}\text { Polyester }+ \\
\left.\text { wt.\% } \% \mathrm{Fe}_{2} \mathrm{O}_{3}\right)\end{array}$ & $\begin{array}{c}\text { Natural } \\
\text { Frequency at } \\
\text { mode 1, Hz }\end{array}$ & $\begin{array}{c}\text { Natural } \\
\text { Frequency at } \\
\text { mode 2, Hz }\end{array}$ & $\begin{array}{c}\text { Natural } \\
\text { Frequency at } \\
\text { mode 3, Hz }\end{array}$ & $\begin{array}{c}\text { Natural } \\
\text { Frequency at } \\
\text { mode 4, Hz }\end{array}$ \\
\hline $\mathrm{P}+0.0$ & 14.66 & 100.10 & 140.00 & 195.00 \\
$\mathrm{P}+1.0$ & 15.02 & 115.60 & 145.02 & 196.48 \\
$\mathrm{P}+1.5$ & 15.99 & 116.16 & 147.32 & 200.43 \\
$\mathrm{P}+2.0$ & 16.40 & 120.29 & 149.42 & 210.75 \\
$\mathrm{P}+2.5$ & 17.42 & 130.48 & 170.54 & 224.23 \\
$\mathrm{P}+3.0$ & 18.71 & 131.70 & 190.25 & 235.40 \\
$\mathrm{P}+3.5$ & 17.01 & 129.46 & 185.35 & 230.09 \\
$\mathrm{P}+6.0$ & 16.52 & 127.88 & 182.04 & 225.77 \\
\hline
\end{tabular}

Note: P-Polyester

\section{CONCLUSIONS}

Two highly nanodisperse $\mathrm{Fe}_{2} \mathrm{O}_{3} \&$ f- $\mathrm{Fe}_{2} \mathrm{O}_{3}$ nanoparticles were synthesized through chemical reduction method and then dispersed into the polyester polymer. Tensile strength, tensile modulus and impact strength and damping characteristics were studied for $\mathrm{Fe}_{2} \mathrm{O}_{3}$ \& $\mathrm{f}-\mathrm{Fe}_{2} \mathrm{O}_{3} /$ polyester nanocomposites. From the SEM analysis it is learnt that addition of $\mathrm{Fe}_{2} \mathrm{O}_{3} \& \mathrm{f}-\mathrm{Fe}_{2} \mathrm{O}_{3}$ nanoparticles impart the changes in the phase transformation from brittle to ductile nature that ultimately rule the improved performance up to optimum weight $\%$, on other hand, beyond optimum level performance is reduced due to the formation of agglomerations and voids due to the increased viscosity of the modified polymer solution. Mechanical properties like tensile strength, modulus and impact strength were optimized due to the same reason as mentioned above. In DSC and TGA analysis it is learnt that addition inorganic nanosuspension in to the polymer were played their role in improvement of thermal stability and curing characteristics. Nanoparticles of iron oxides nanocomposites can be used as ferrofluids, high-density information storage, magnetic resonance imaging (MRI), tissue-specific releasing of therapeutic agents, biomechanical applications.

\section{Acknowledgements}

Authors would like to thank the Department of Polymer Science and Technology, S.K. University, Anantapur and RV College of Engineering, Bangalore, India for giving their support in completion of our research. 


\section{References}

[1] Chen, Y.; Sun, L.; Chiparus, O.; Negulescu, I.; Yachmenev, V.; Warnock, M.(2005). Kenaf/ramie composite for automotive headliner. J Polym. Envint.2005, 13,107-114.

[2] Podlaha, E.J.; Landolt, D. Pulse-reverse plating of nanocomposite thin films. Journal of Electrochemical Society, 1997, 144, 200-202.

[3] Castro, C.; Ramos, J.; Millan, A.; Gonzalez-Calbet, J.; Palacio, F. Production of magnetic nanoparticles in imine polymer matrixes. Chemical Materials, 2000, 12, 3681-3688.

[4] Wetzel, B.; Haupert, F.; Zhang, M.Q. Epoxy nanocomposites with high mechanical and tribological performance. Composite Science and Technology, 2003, 63, 2055-2067.

[5] Guo, Z.; Park, S.; Wei, S.; Pereira, T.; Moldovan, M.; Karki, A.B. Flexible high-loading particle-reinforced polyurethane magnetic nanocomposite fabrication through particlesurface-initiated polymerization. Nanotechnology, 2007, 18,335-340.

[6] Kohli, N.; Worden, R.M.; Lee, I. Intact transfer of layered, bionanocomposite arrays by microcontact printing. Chemical Communications, 2005, 3, 316-318.

[7] Judeinstein, P.; Sanchez, C. Hybrid organic-inorganic materials: a land of multidisciplinarity. Journal of Materials Chemistry, 1996, 26, 511-525.

[8] Zhang, X.; Simon, L.C. In situ polymerization of hybrid polyethylene- alumina nanocomposites. Macromolecular Material Engineering, 2005, 290,573-583.

[9] Gao, S.L.; Mader, E. Characterization of inter phase nanoscale property variations in glass fibre reinforced polypropylene and epoxy resin composites. Composites A, 2002, 33:559576.

[10] Shenhar, R.; Norsten, T.B.; Rotello, V.M. Polymer-mediated nanoparticle assembly: structural control and applications. Advanced Materials, 2005, 17, 657-669.

[11] Guo, Z.; Pereira, T.; Choi, O.; Wang, Y.; Hahn, H.T. Surface functionalized alumina nanoparticle filled polymeric nanocomposites with enhanced mechanical properties. Journal of Materials Chemistry, 2006, 16, 2800-2808.

[12] Guo, Z.; Wei, S.; Shedd, B.; Scaffaro, R.; Pereira, T.; Hahn H.T. Particle surface engineering effect on the mechanical, optical and photoluminescent properties of $\mathrm{ZnO} /$ vinylester resin nanocomposites. Journal of Material Chemistry, 2007,17, 806-813.

[13] Guo, Z.; Liang, X.; Pereira, T.; Scaffaro, R.; Hahn, H.T. CuO nanoparticles filled vinyl-ester resin nanocomposites: fabrication, characterization and property analysis. Composite Science and Technology, 2007, 67, 2036-2044.

[14] Rancourt, J.D.; Taylor, L.T. Preparation and properties of surface conductive polyimide films via in situ co-deposition of metal salts. Macromolecules, 2008, 20, 790-795.

[15] Sawada, T.; Ando, S. Synthesis, Characterization, and Optical Properties of MetalContaining Fluorinated Polyimide Films. Chemistry Materials, 2009, 10, 3368-3378.

[16] Chiang, P.C.; Whang, W.T. The synthesis and morphology characteristic study of bao-odpa polyimide/tio 2 nanohybrid films. Polymer, 2003, 44, 2249-2254.

[17] Hsu, S.C.; Whang, W.T.; Hung, C.H.; Chiang. P.C.; Hsiao, Y.N. Effect of the Polyimide Structure and $\mathrm{ZnO}$ Concentration on the Morphology and Characteristics of Polyimide/ZnO Nanohybrid Films. Macromolecular Chemistry Physics, 2005, 206, 291-298.

[18] Liu, L.; Zhang, T.J.; Cui, K.; Dong, Y.D.(1999). Reduction of copper oxide with graphite by mechanical alloying. Journal of Material Research, 1999, 14, 4062-4069. 
[19] Park, S.S.; Bernet, N.; Roche, S.D.L.; Hahn, H.T. Processing of iron oxide-epoxy vinylester nanocomposites. Journal of Composite Materials, 2003, 37,465-476.

[20] Sorensen, C.M. Magnetic Nanoscale Materials in Chemistry. In: Klabunde KJ, editor. Nanoscale Materials in Chemistry. New York: Wiley-Interscience; 2001, 69-221.

[21] Zhang, D.; Klabunde, K.J.; Sorensen, C.M.; Hadjipanayis, G.C. Magnetization temperature dependence in iron nanoparticles. Physical Review B, 1998, 58,14167-14170. 